\title{
1995年兵庫県南部地震における基礎有効入力動に関する考察 EXAMINATION ON EFFECTIVE INPUT MOTION TO STRUCTURES IN HEAVILY DAMAGED ZONE IN THE 1995 HYOGO-KEN NANBU EARTHQUAKE
}

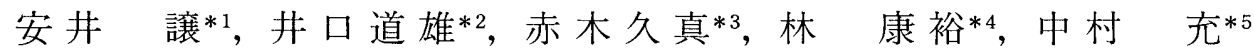 \\ Yuzuru YASUI, Michio IGUCHI, Hisanobu AKAGI, \\ Yasuhiro HA YASHI and Mitsuru NAKAMURA
}

\begin{abstract}
There are a few stations in which strong earthquake motions were recorded simultaneously at structural foundations and on surface of the ground in the 1995 Hyogo-ken Nanbu earthquake. Comparing the maximum accelerations observed at the foundations with those on the ground surface shows that the former is reduced $30 \%$, and $10 \%$ for velocity on average. In the area considered to have experienced more severe ground motions e.g. such as larger than 400 gal corresponding to the second step threshold of the present building code of Japan, there are no simultaneous recording stations. The surface ground motions are simulated backward from the records of two structures in and near severely damaged zone using soil-structure interaction theory considering non-linearity of both structure and ground. Calculated results show similar reduction tendency to the above-mentioned observed results. It is also deduced that the reduction of peak values on the foundation to the ground surface resulted from amplification of soil layer over the bottom of the structure.
\end{abstract}

keywords Hyogo-ken Nanbu earthquake, Soil-structure interaction, Effective input motion, Response analysis, Strong motion record

兵庫県南部地震、相互作用、基礎有効入力動、応答解析、強震観測記録

1 はじめに

1995 年兵庫県南部地震において激震地となった神戸市域では、最 大加速度 300 800gal、最大速度 50〜120kine の高加速度·高速度の 観測記録が得られた。これらの観測記録のうち建物内で観測された記 録の最大值やスペクトルが概して地盤において観測された記録に比べ て小さい傾向を示したことから、相互作用の効果による入力低减効果 が注目され 1)，2）、建物の応答に及ぼす相互作用効果の影響に関する 研究が少なからず発表されてきた。

林他 ${ }^{3)}$ は、神戸駅断面の地動の再現を試み、その妥当性を NTT 神戸 駅前ビルの地下 3 階の記録との比較により確認した後、地下階を有す る 3、5、および 10 階建の建物の相互作用解析を行っている。その結 果、上部構造物の応答はその非線形特性によって大きく影響を受けて 変化するが、地下階の忘答にはほとんど差が無く、同一レベルの自由 地盤の応答とほぼ同じであるとみなせるとしている。また、二宮 ${ }^{4}$ は、 上記の駅前ビルの観測記録を 2 次元 FEM モデルを用いてシミュレーシ ヨン解析を行うとともに、建物の周辺地盤と遠方自由地盤の地震動に 関する検討を行っている。

田村他 ${ }^{5)}$ は、13 階建と 11 階建の $2 つ$ SRC 造被災建物につい て埋込みを考慮した相互作用解析を行い、建物の基礎底面位置の 応答と自由地盤の基礎底面位置の応答の大きさはほぼ同等とみな すことができるとし、基礎固定モデルに自由地盤の基礎底面位置
の応答波を入力することで簡易的に建物の応答を評価できるとし ている。さらに、支持地盤の違いにより地盤の非線形化に起因し た連成系の減衰定数の増大化傾向が異なり、建物の応答特性が変 化するとしている。

栗本 ${ }^{6\rangle}$ は、高層 R C 構造物の観測記録のシミュレーション解析 を行い、剛性が高くその底面が硬質な地盤に支持された基礎を有 する建物に対しては、基礁側面の表層地盤の非線形性がその応答 に与える影響は小さいとしている。また、藤森他 ${ }^{7)}$ は同じ観測記 録を用いて基礎有効入力動の低减効果について検討している。 金田他 ${ }^{81}$ は、被害が小破であった地下階のある S 造 8 階建の建 物について 2 次元 FEM 等価線形解析を行い、地下階があることに より建物への入力が地表面の地震動に対してどのように低減され るかを検討している。その結果、地表面に比べ、建物への入力は 最大加速度で約 $16 \%$ 低減され、層間変位は最大で $14 \%$ 低減したとし ている。

半澤他 ${ }^{9)}$ は、比較的やわらかい地盤（地盤の $\mathrm{S}$ 波速度が $160 \mathrm{~m} / \mathrm{s}$ ） を対象として建物の応答低减効果を検討している。その結果、建物一 基礎一地盤系の 1 次固有周期に対するベースシア係数は、地盤ばねを 考慮することによりその值が基礎固定に比べて $50 \%$ 减となり得ると している。また、基礎浮上りを考慮することにより建物の応答が低減 される傾向にあることが指摘されている。

\footnotetext{
${ }^{* 1}$ (侏)大林組技術研究所振動研究室 空長 $・$ 工博

*2 東京理科大学理工学部建築学科 教授・工博

*3 (蛛) NTTファシリティーズ研究開発部 主席研究員・工博

*4 清水建設烌和泉研究室 主任研究員・工博

*5 蚮大林組技術研究所振動研究室 副主任研究員
}

General Manager, Vibration Engineering Department, Technical Research Institute, Obayashi Corporation, Dr. Eng.

Prof., Department of Architectural Engineering, Faculty of Science and Engineering, Science Univ. of Tokyo, Dr. Eng.

Executive Research Engineer, Research and Development Department, NTT Power and Building Facilities Inc., Dr. Eng.

Chief Research Engineer, Izumi Research Institute, Shimizu Corporation, Dr. Eng. Deputy Chief Research Engineer, Vibration Engineering Department, Technical Research Institute, Obayashi Corporation 


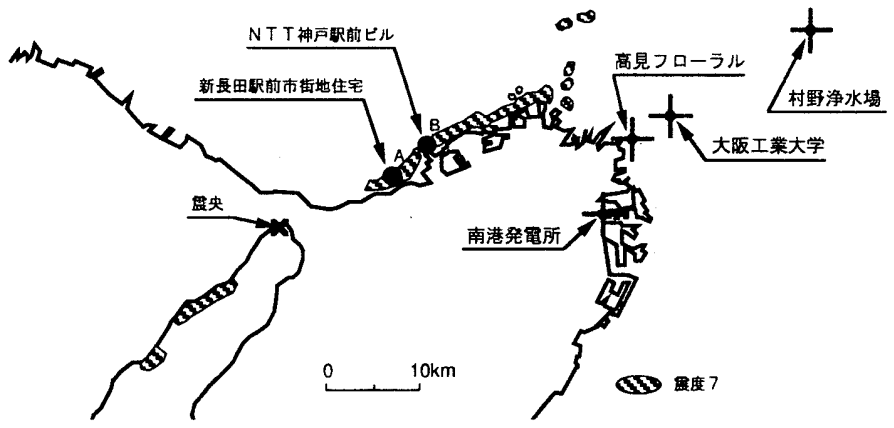

図 1 構造物の位置

表 1 構造物の概要

\begin{tabular}{|c|c|c|c|c|c|}
\hline & $\begin{array}{c}\text { 高見フロー } \\
\text { ラル }{ }^{12)}\end{array}$ & $\begin{array}{c}\text { 南港発電所 } \\
\text { 煙突 }{ }^{13)}\end{array}$ & $\begin{array}{c}\text { 南港発電所 } \\
\text { 本館 }{ }^{15)}\end{array}$ & $\begin{array}{l}\text { 大阪工業 } \\
\text { 大学 }{ }^{16)}\end{array}$ & \begin{tabular}{|c} 
村野浄水場 \\
177
\end{tabular} \\
\hline 上部構造 & RCラーメン & RC造 & $\mathrm{S}$ 造 & SRC ラーメy & $\mathrm{RC}$ ラーメ \\
\hline 基礎構造 & 場所打 RC 杭 & $\begin{array}{l}\text { 上部: } \mathrm{SC} \text { 杭 } \\
\text { 下部: } \mathrm{PHC} \text { 杭 }\end{array}$ & $\begin{array}{l}\text { 上部:SC 杭 } \\
\text { 下部:PHC 杭 }\end{array}$ & 場所打 $\mathrm{RC}$ 杭 & 場所打 $\mathrm{RC}$ 杭 \\
\hline 建築面積 & $989.5 \mathrm{~m}^{2}$ & 271.6 & 13817.0 & 788.0 & 6531.4 \\
\hline 建屋高さ & $98.2 \mathrm{~m}$ & 200 & 31.0 & 65.65 & 37.7 \\
\hline 埋込み深さ & $8.3 \mathrm{~m}$ & 6.3 & $4.0 \sim 12.3$ & 5.2 & 14.8 \\
\hline 杭長 & $22.75 \mathrm{~m}$ & 64.5 & $62 \sim 70$ & 20.3 & $12 \sim 16$ \\
\hline 杭径 & $2.3 \mathrm{~m}$ & 0.8 & 0.8 & $1.8,2.0$ & 2.0 \\
\hline 杭本数 & 56 & 273 & 2449 & 24 & 422 \\
\hline 表層地盤 Vs & $140 \sim 240 \mathrm{~m} / \mathrm{s}$ & $160 \sim 350$ & $160 \sim 350$ & $130 \sim 150$ & - \\
\hline 支持地盤 Vs & $380 \mathrm{~m} / \mathrm{s}$ & 340 & 340 & 320 & - \\
\hline $\begin{array}{l}\text { 固 有 周 期 } \\
\text { NS, EW }\end{array}$ & $\begin{array}{c}1.41,1.45 \\
\text { sec. }\end{array}$ & 1.87 (NS) & 0.93 (NS) & $0.83,0.92$ & $0.437,0.439$ \\
\hline $\begin{array}{c}\text { 地震 計位 置 } \\
\text { (地表面) }\end{array}$ & GL-1.5 m & $\mathrm{GL}-0.1 \mathrm{~m}$ & GL- $-0.1 \mathrm{~m}$ & $5 \mathrm{~m}$ & $\mathrm{GL}^{-}$ \\
\hline $\begin{array}{c}\text { 地震計位置 } \\
\text { (基礎上) }\end{array}$ & $1 \mathrm{FL}$ & $\mathrm{GL} \pm 0 \mathrm{~m}$ & $1 \mathrm{FL}$ & IFL & $\begin{array}{c}\mathrm{B} 2 \mathrm{~F} \\
(\mathrm{GL}-10.8 \mathrm{~m}) \\
\end{array}$ \\
\hline
\end{tabular}

基礎の浮上がりの影響については、林 ${ }^{10)}$ により詳細な検討がなさ れている。この研究は、激震地に建つある建物が被害軽微であった原 因を検討した結果、相互作用効果によりある程度説明がつくが、さら

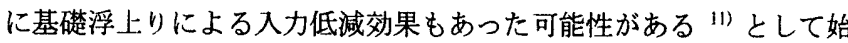
められたものである。これらの検討結果によれば、地盤が硬く建物が スレンダーな場合に応答低減効果が期待されるとしている。

杭基礎を有する構造物のシミュレーション解析については、横山 12)、あるいは古和田他 ${ }^{13)}$ の報告がある。いずれも杭支持位置の観測 記録を入力する Penzien 型モデルで上部構造物の観測記録を精度よく 近似できたとしている。また、宮本他 ${ }^{14)}$ は、ポートアイランドに建 つ杭支持建物を対象として、入力レベルをパラメータとした地震応答 解析を行っている。地震入力が大きくなり、地盤に液状化が生じると、 基䃈入力動のスペクトルは自由地盤地表面のものに比べて全周期帯域 で大きくなることがあるとしている。

以上に述べたように構造物と地盤との相互作用に起因する入力低減 効果、あるいは基礎有効入力動に関する研究が精力的に行われてきて いるが、地盤と建物の観測記録を直接的に比較することにより激震地 域における相互作用効果の検討を試みた例は少ないと言える。そこで 本論文ではまず、地表面之建物基礎で得られた強震地域における同時 観測記録から大略的に相互作用効果の傾向を把握した後、続いて震度 7 やその近傍の激震地で得られた建物地下階の記録から自由地表面地

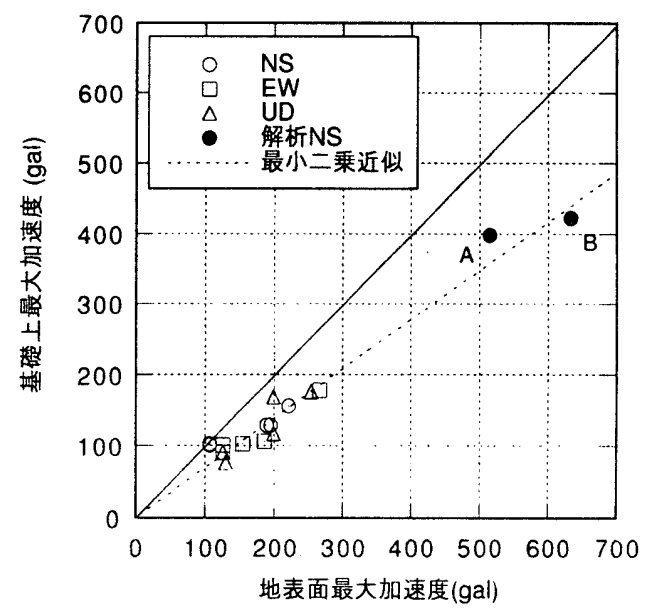

図2 地表面と基礎の最大加速度

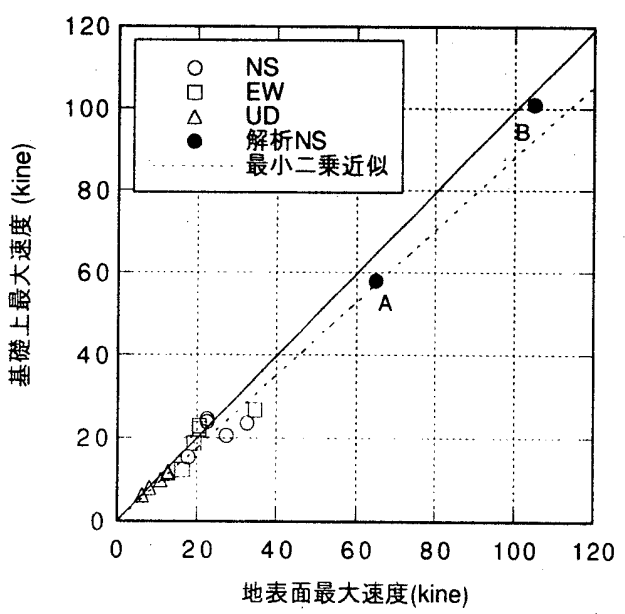

図 3 地表面と基礎の最大速度

動の逆算推定を行ない、激震地域における建物への入力地震動につい ての評価検討を行うこととした。

なお、本論文のタイトルに含まれる基礎有効入力動とは、地震時に 相互作用の影響を受けた建物基礎の動きのことを言い、特に自由地盤 地表面の動きと対比させる場合に用いられる。この基礎有効入力動は 基礎固定の建物モデルの入力動となるものである。

\section{2. 地表面と建物基礎での同時観測記録の比較}

地盤と建物基礎とで同時観測された記録はそれほど多くはない。 表 1 に强震地域で同時観測された構造物（建物 4 件と煙突 1 件）の 概要を示した。図 1 にこれらの構造物の位置を示す。同図には、後 述する新長田駅前市街地住宅 $\left(\bigcirc^{A}\right)$ と NTT 神戸駅前ビル $\left(\bigcirc^{\mathrm{B}}\right)$ の 位置も示してある。図 2 に基礎上の記録と地表面の記録の最大加速 度を、図 3 に最大速度を比較して示す。これらの観測地点の地盤の 測点位置は GL. - $0.1 \mathrm{~m} \sim-1.5 \mathrm{~m}$ の哚さにあり、ほぼ地表面と考えてよ い。一方、構造物基礎の観測点については 4 件が 1 階あるいは地表 レベルである。残りの 1 件の観測点は地下 2 階（GL-10.8m）である が、当該建物の地下室の剛性が高いため 1 階の動きと大きな差はな いと考えられる。図 2、3において、○、ロおよび れ NS、EW およびUD 成分の観測值である。最大加速度值に関して、 地表面に対する基䂿の比率を直線で最小二乗近似するとその傾きは 


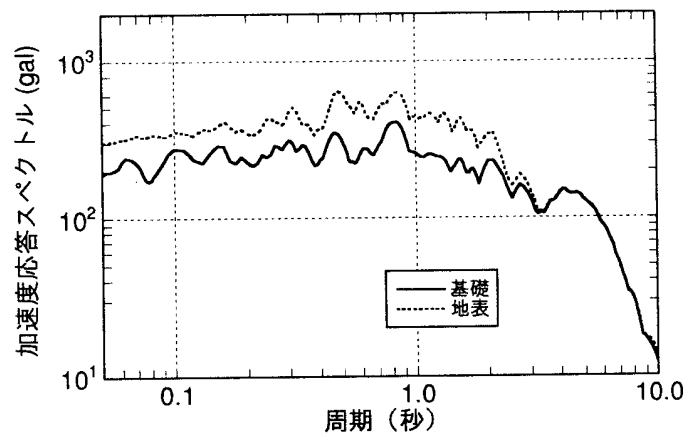

図 4 地表面と基礎の応答スペクトル $(\mathrm{EW}, \mathrm{h}=5 \%)$

ほぼ 0.7 となる。すなわち、基礎上の最大加速度值は地表面に対し 3 割低下している。一方、速度に関して同様に最大值を最小二乗近 似すると 0.9 となり、加速度に比べて低減率が小さい結果となった。 図 4 に、図 2 の観測值の中でもっとも大きな加速度を記録した地 点における、地表面（GL-1.5m）と基礎 ${ }^{12}$ )の忍答スペクトルを比較 したものを示す。同図から、2 秒より短い比較的広い周期成分で基 礎有効入力動の低減効果が認められる。

ところで図 2、3に示された記録には震災の帯、いわゆる激震地 での記録は含まれていない。そこで、次章では建物の基礎の記録か ら激震地の自由地表面の地動を逆算し同様な傾向が見られるかどう

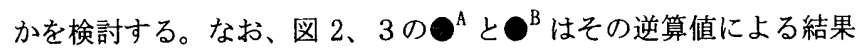
を示したものである。

\section{3．激震地での地表面地動の推定}

\section{1 推定手法概要}

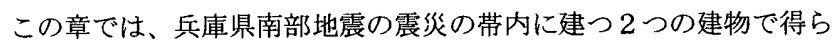
れた地震観測記録を基に自由地表面地動の逆算推定を行ない、強震時 における建物への入力地震動についての評価検討を行う。

建物で観測された強震記録から自由地表面の地震動を逆算する手法 18)の概略を以下に示す。

まず、建物の基礎固定弾塑性モデルを作成し、建物基礎もしくは基 礎に淮ずる地下階で得られた観測地震波 $u_{\mathrm{B}}(t)$ を用いて建物の弾塑性 応答解析を行なう。解析の結果得られた応答を建物上部階での観測地 震波と比較し、建物モデルが地震時の応答をよく再現していることを 確認する。

次に、建物周辺地盤の地盤構造モデルを作成し、基礎のインピーダ ンス（無質量剛基礎のばねと減衰）と基礎入力動（地表面に対する無 質量剛基礎の伝達関数）を求める。解析手法は埋込を考慮できる薄層

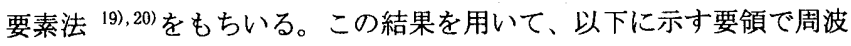
数領域における解析を行なう。

基礎入力動 $u_{\mathrm{C}}(t)$ 、自由地表面動 $u_{\mathrm{F}}(t)$ のフーリエ変換をそれぞれ、 $U_{C}(\omega) 、 U_{F}(\omega)$ とし、これらと基礎入力動 $H(\omega)$ との関係が

$$
U_{C}(\omega)=H(\omega) U_{F}(\omega)
$$

で与えられているものとする。基礎の質量を $m_{0}$ 、基礎のインピー ダンスを $K_{H}(\omega)$ とし、慣性の相互作用による変位のフーリェ变換を $U_{0}(\omega)$ 、上部構造物が基礎に及ぼす時刻歴せん断力 $q(t)$ のフーリエ変 換を $\mathrm{Q}(\omega)$ とすると、運動方程式は、

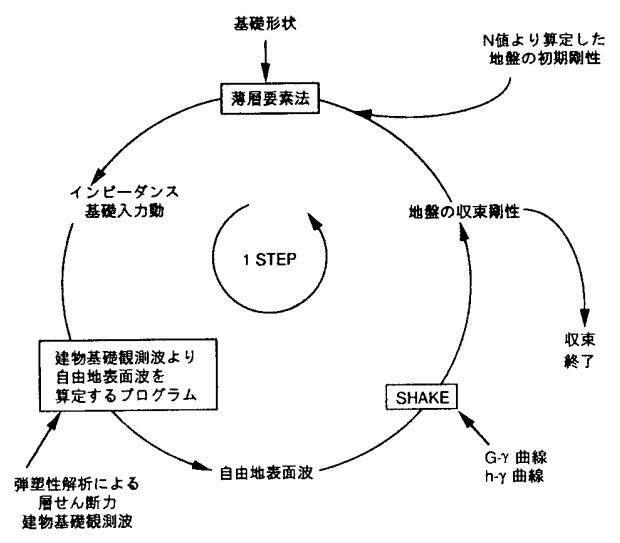

図 5 逆算フロー概略図

$$
-m_{0} \omega^{2}\left(U_{C}(\omega)+U_{0}(\omega)\right)+K_{H}(\omega) U_{O}(\omega)=Q(\omega)
$$

となる。ここに $q(t)$ は前述した建物モデルによる弾塑性応答解析にお ける結果を用いる。

さらに、基礎上での観測波 $u_{\mathrm{B}}(t)$ (ここでは建物地下階の観測波を もって代用する）のフーリェ変換 $U_{B}(\omega)$ は次式で表される。

$$
U_{B}(\omega)=U_{C}(\omega)+U_{0}(\omega)
$$

以上の関係から、 $U_{F}(\omega)$ は次のように求められる。

$$
U_{F}(\omega)=\frac{1}{H(\omega)}\left\{U_{B}(\omega)-\frac{Q(\omega)+m_{0} \omega^{2} U_{B}(\omega)}{K_{H}(\omega)}\right\}
$$

自由地表面波の時刻歷 $u_{\mathrm{F}}(t)$ は $U_{F}(\omega)$ の逆フーリエ変換から得られ る。こうして求めた $u_{\mathrm{F}}(t)$ を用いて自由地盤の等価線形化解析を行い、 逆算された地表面波のひずみレベルに対応する基礎のインピーダンス $K_{H}(\omega)$ と基礎入力動 $H(\omega)$ を再計算する。これらの $K_{H}(\omega)$ と $H(\omega)$ を用 いて同様の方法で新たに自由地表面波を求める。この計算を、前段階 の推定結果とほぼ一致するまで繰り返す。

図 5 に以上に述べた手法のフロー概略図を示す。この手法の特徵は、 建物と地盤の双方の非線形性を考慮しながら強震記録から自由地表面 動が推定できることにある。なお、この逆解析手法では Local nonl inearity の影響は考慮していない。また、以上に示した手法で はスウェイに関するインピーダンスのみを考慮しているが、以下の 2 つの事例においては事前にロッキングも考慮した構造物一基礎一地盤 系の伝達関数を求め、ロッキングの影響が殆どないことを確認してい る。

\section{2 新長田駅前市街地住宅}

住宅・都市整備公団新長田駅前市街地住宅 ${ }^{21)}$ は J R 新長田駅前に建 つS R C 造地上 25 階地下 3 階建の高層建物であり、兵庫県南部地震 では気象庁により震度 7 と判定された激震地域に位置する。図 6 に建 物の東西梁間方向断面と高層階平面図を示す。

兵庫県南部地震におけるこの建物の被害は、南北方向の析行構面の ほうが東西方向の梁間構面よりも大きかった。特に損傷が著しいのは 住戸と中榔卜閒に設けられた小梁・雑壁構面であり、ほとんどの小梁 が住下出入口の開口部でせん断破壊しており、雑壁には大きなせん断 ひび割れが生じていた。 


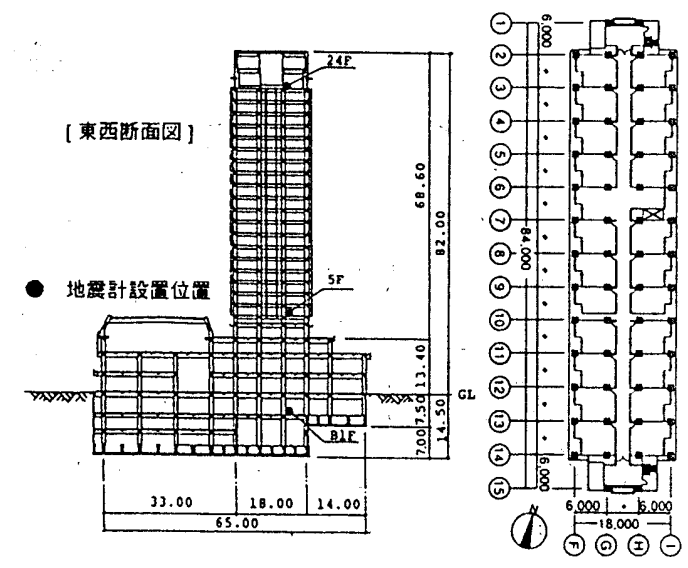

図 6 新長田駅前市街地住宅の建物断面之高層階平面図

表 2 観測地震波の加速度最大値（gal）

\begin{tabular}{|c|c|c|c|c|c|c|}
\hline & \multicolumn{2}{|c|}{ N S } & \multicolumn{2}{|c|}{ E W } & \multicolumn{2}{c|}{ U D } \\
\hline & $\begin{array}{c}\text { 観測 } \\
\text { 結果 }\end{array}$ & $\begin{array}{c}\text {. 補間 } \\
\text { 結果 }\end{array}$ & $\begin{array}{c}\text { 観測 } \\
\text { 結果 }\end{array}$ & $\begin{array}{c}\text { 補 } \\
\text { 結果 }\end{array}$ & $\begin{array}{c}\text { 観測 } \\
\text { 結果 }\end{array}$ & $\begin{array}{c}\text { 補間 } \\
\text { 結果 }\end{array}$ \\
\hline 24 階 & $635 *$ & 956 & $302 *$ & 354 & 327 & - \\
\hline 5 階 & $379 *$ & 407 & 183 & - & - & - \\
\hline 地下 1 階 & $315 *$ & 354 & 121 & - & 119 & - \\
\hline
\end{tabular}

表 3 地盤諸定数

\begin{tabular}{|c|c|c|c|c|c|}
\hline \multirow[b]{2}{*}{ 樑さ (m) } & \multirow[b]{2}{*}{ 主な土質 } & \multicolumn{2}{|c|}{ 初期地盤 } & \multicolumn{2}{|c|}{ 収束地盤 } \\
\hline & & $\begin{array}{c}\mathrm{Vs} \\
(\mathrm{m} / \mathrm{sec})\end{array}$ & $\begin{array}{c}\text { 密度 } \\
\left(\text { ton } / \mathrm{m}^{3}\right)\end{array}$ & $\begin{array}{c}\text { Vs' } \\
(\mathrm{m} / \mathrm{sec})\end{array}$ & $\mathrm{h}^{\prime}$ \\
\hline GL0-2.8 & 埋土 & 125.0 & 1.8 & $114-122$ & $0.03-0.05$ \\
\hline $2.8-5.0$ & 砂 & 210.2 & 1.8 & 200 & 0.04 \\
\hline $5.0-6.8$ & 粘土 & 209.7 & 1.8 & 192 & 0.04 \\
\hline $6.8-10.9$ & 砂磷 & 324.3 & 1.9 & 239 & 0.10 \\
\hline $10.9-14.0$ & 粘土 & 229.2 & 1.8 & 198 & 0.06 \\
\hline $14.0-17.4$ & 砂磷 & 337.0 & $\cdot 1.9$ & 219 & 0.13 \\
\hline $17.4-21.8$ & 凝固粘土 & 271.9 & 1.8 & $233-236$ & 0.06 \\
\hline $21.8-26.3$ & シルト質細砂 & 313.9 & 1.8 & 276 & 0.05 \\
\hline 26. 3-29. 8 & 凝固粘土 & 278.3 & 1.8 & 233 & 0.07 \\
\hline $29: 8-37.0$ & 固結粘土 & 296.0 & 1.8 & $250-252$ & 0.06 \\
\hline $37.0-40.0$ & 喽混じり細砂 & 450.0 & 1.9 & 306 & 0.12 \\
\hline
\end{tabular}

この建物では、建設当初に設置された地震計により地震観測が継続 的に行なわれてきており ${ }^{22)}$ 、兵庫県南部地震では、24 階・5 階・地 下 1 階の 3 力所で地震の記録に成功したが、この地震動は地震計が設 置された時点で想定された地震動の大きさをはるかに上回っており、 一部の記録はオーバースケールしてしまっている。表 2 に観測された 時刻歴加速度波形の最大值を、スプライン関数によるオーバースケー ル補間結果と共にまとめて示す。表中＊印を付したものはオーバース ケールしていることを示す。地表面地動の逆算は、この記録の内最大 值が大きい南北方向を対象として行なった。

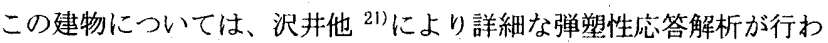
れている。本論文では、沢井他により作成された建物モデルを用いる。 モデルは立体骨組モデルの静的解析に基づいて作成された質点系モデ ルであり、地下 1 階基礎固定となっている。减衰注初期用性比例型の 内部粘性減衰とし、減衰定数は 1 次モードに対して $3 \%$ とした。この モデルの固有周期は 1 次モードで 1.07 秒であり、後述する地盤ばね

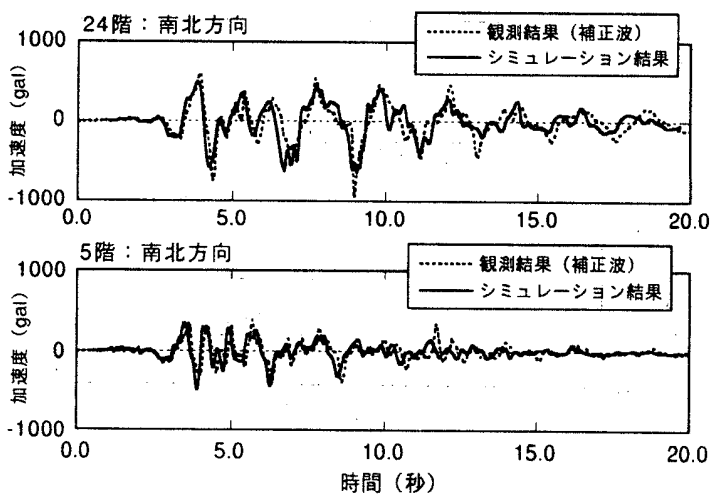

図 7 弹塑性応答解析結果と観測波形の比較 ${ }^{21)}$

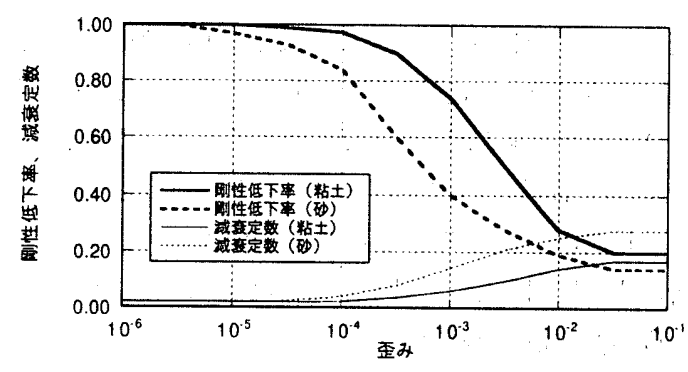

図 8 地盤の歪み依存特性

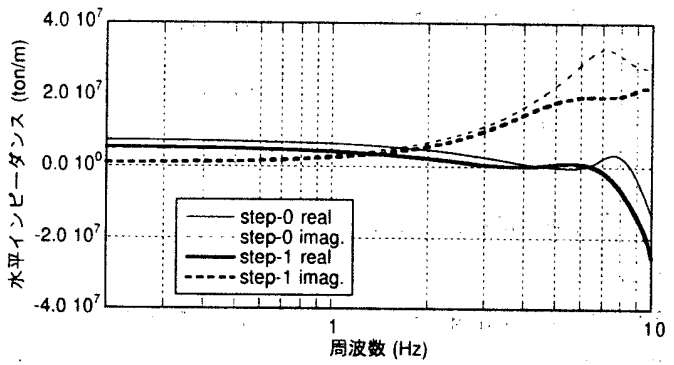

図 9 基䃈のインピーダンス

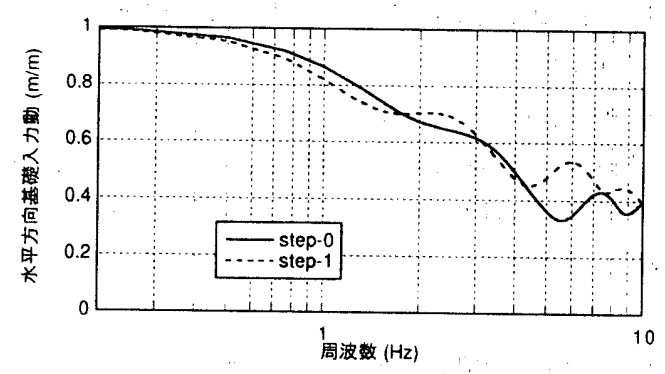

図 10 基䃈入力動

を考慮した場合の固有周期は 1.08 秒である。

この質点系モデルに地下 1 階観測波を入力し弾塑性応答解析が行な われている ${ }^{21)}$ 。24. 階と 5 階の応答加速度波形を観測波と比較して図 7 に示す。 24 階・5 階とも 10 秒付近までは解析結果は観測波とよく 対忍している。

次に地盤モデルの作成であるが、この建物周辺地盤の弾性波速度構 造に関しては害測に基づくデータがなかったため、地盤の柱状図情報 に基づき $\mathrm{N}$ 值から推定した ${ }^{23)}$ 。表 3 に地盤モデルの初期地盤物性值 を示す。また、等価線形化解析に際して必要となる地盤物性値の歪み 依存特性（G- $\gamma 、 \mathrm{~h}-\gamma$ 曲線）は既往の資料 ${ }^{24)}$ を基に推定した。用い 


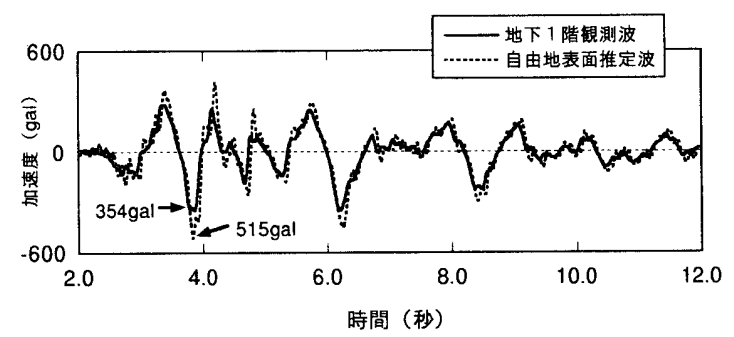

図 11 地表面推定波加速度波形

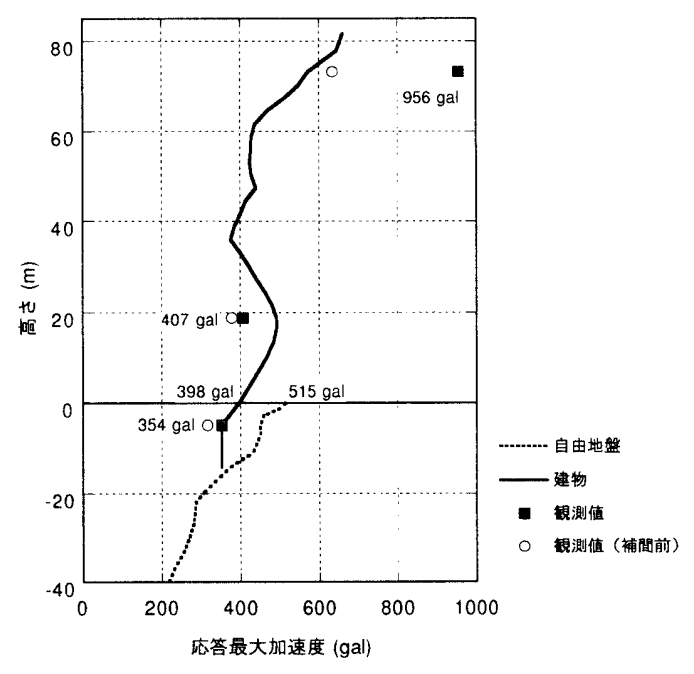

図 12 最大応答加速度分布図

た值を図 8 に示す。

このモデルを用いて、前述した手法で自由地表面地動を逆算推定し た。図9に基礎のインピーダンスを、図 10 に基礎入力動をそれぞれ 示す。図中には初期地盤に対応するもの (Step-0) と 1 回目の繰り返 し時のもの（Step-1）とを示寸。今回の解析では、1 回の繰り返しで 結果がほぼ収束したことから 1 回目の繰り返し時の結果が最終推定時 の結果になっている。表 3 には、収束時の地盤のせん断波速度 Vs'と 減衰定数 h'を示してある。なお、1 次元土柱の解析は表 3 の各層を 細分割してモデル化しており、収束後の定数が範用で示されているも のは細分割層ごとに值が異なっていることを示している。また、収束 時の地盤の歪みレベルは、もっとも大きな層で $0.0018(0.18 \%)$ 程度で あった。

得られた自由地表面加速度波形を地下 1 階における観測波と比較し て図 11 に示す。最大值で見ると、観測波（補正波）の354gal に対し 地表面推定波では $515 \mathrm{gal}$ と約 $45 \%$ の増加（地表面に対し地下 1 階で は約 $30 \%$ の减少）になっていることがわかる。

図 12 には建物と自由地表面の最大加速度分布を示す。図中には建 物における観測結果も併記して示す。自由地表面の基礎底面位置以浅 の地盤の堌幅が大きいこと、ならびに建物地下階の観測值は基礎底面 位置の自由地表面と同程度の値を示すこと等が注目される ${ }^{3) 、 5) 。 ~}$

次に、基礎有効入力動の低減効果について地表面高さで比較検討す るため、自由地表面波と、同じ高さでの建物忍答すなわち地下 1 階固 定モデルに地下 1 階観測波を入力した際の 1 階応答波との比較を行な う。図 13 に、地表面推定波と 1 階応答波との波形の比較を示す。最 大值で見ると、地表面推定波の $515 \mathrm{gal}$ に対し 1 階応答波では $398 \mathrm{gal}$ と約 $23 \%$ の減少になっていることがわかる。最大速度の比較では、

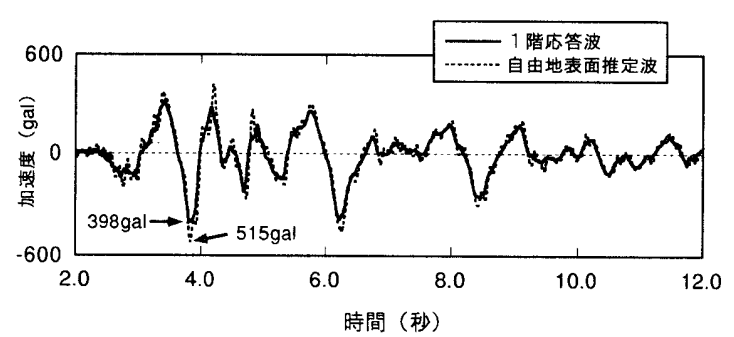

図 13 地表面推定波と 1 階応答波の比較

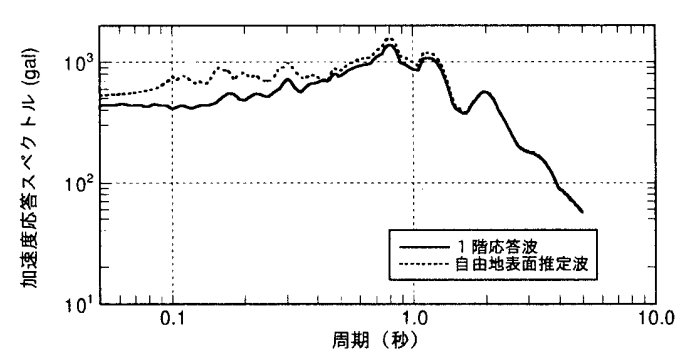

図 14 応答スペクトルの比較

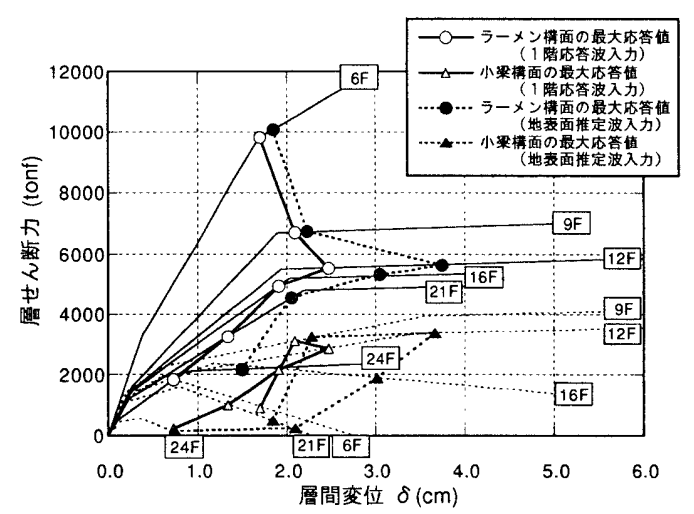

図 15 最大応答層せん断力

地表面推定波の $65 \mathrm{kine}$ に対して1階応答波では $58 \mathrm{kine}$ と、約 $10 \%$ の減少となっている。これらの值を建物基礎の観測值と比較して図 2、 3 に示す (@A)。図から、同時観湘記録と同様な傾向を示している ことが確認される。自由地表面波と 1 階応答波とを加速度応答スペク トルで比較したものを図 14 に示す。図から、1 秒前後から自由地表 面と 1 階応答との差がわずかにみられ、0.4 秒程度より短周期では差 が大きくなることが分かる。これは図 10 に示された基礎入力動によ る効果が現れているものと考えられる。

次に、前述の質点系弹塑性モデルを 1 階固定としたものに地表面推 定波を入力して応答解析を行い、同じモデルに 1 階応答波を入力した 結果（地下 1 階固定モデルに地下 1 階観測波を入力したものと同じ結 果となる）とどのような差が生じるかを比較した。応答解析結果を層 間最大応答で比較したものを図 15 に示す。図から、ラーメン構面の 最大忘答を見ると 6 階や 9 階ではわずかな差しか見られないが、 12 階以上での差は大きく、特に 16 階や 24 階では 1 階応答波入力では降 伏点に達していなかったものが、地表面推定波入力では大きく変形が 進んでいることがわかる。

\subsection{NTT神戸駅前ビル}

$\mathrm{NTT}$ T神戸駅前ビル ${ }^{4)}$ は、J R 神戸駅前に位置する S R C 造地上 8 階地下 3 階建の建物である。図 16 に建物の東西方向断面と地下 3 階 

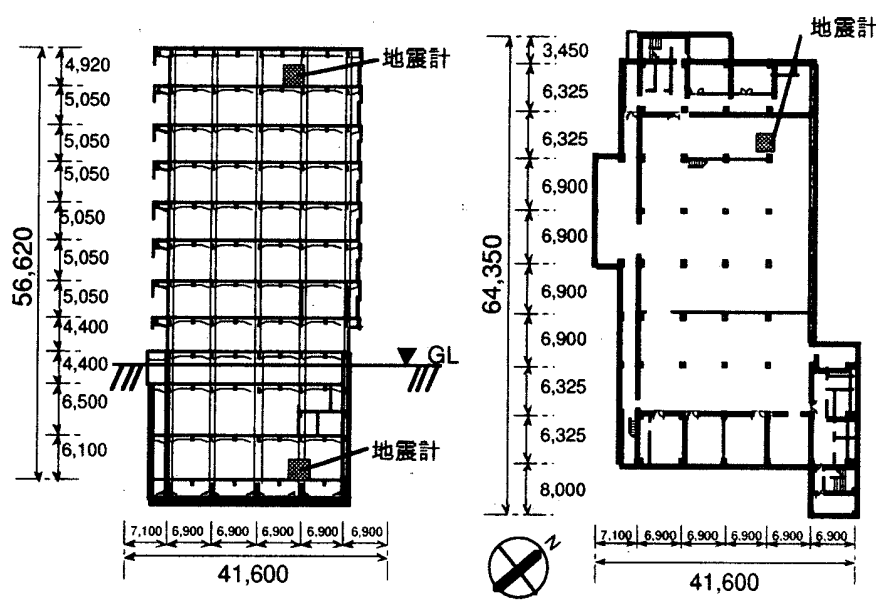

図 16 N T T神戸駅前ビルの建物断面と B 3 F 平面図

表 4 観測地震波の加速度最大值（gal）

\begin{tabular}{|c|c|c|c|}
\hline & N S & E W & UD \\
\hline 8階 & 881 & 504 & 408 \\
\hline 地下 3 階 & 331 & 154 & 169 \\
\hline
\end{tabular}

表 5 地盤諸定数

\begin{tabular}{|c|c|c|c|c|c|}
\hline \multirow[b]{2}{*}{ 媣さ (m) } & \multirow[b]{2}{*}{ 主な土質 } & \multicolumn{2}{|c|}{ 初期地盤 } & \multicolumn{2}{|c|}{ 収束地盤 } \\
\hline & & $\begin{array}{c}V s \\
(\mathrm{~m} / \mathrm{sec})\end{array}$ & $\begin{array}{c}\text { 密度 } \\
\left(\text { ton/ } / \mathrm{m}^{3}\right)\end{array}$ & $\begin{array}{c}V s^{\prime} \\
(\mathrm{m} / \mathrm{sec})\end{array}$ & $h^{\prime}$ \\
\hline GLO-2.0 & 埋土 & 90.0 & 1.6 & $66-85$ & $0.04-0.15$ \\
\hline 2. $0-5.0$ & 砂 & 130.0 & 1.8 & $46-73$ & $0.22-0.28$ \\
\hline $5.0-10.0$ & 砂碟 & 190.0 & 1.9 & $75-105$ & $0.22-0.27$ \\
\hline $10.0-20.0$ & 砂質 & 250.0 & 1.9 & $100-134$ & $0.23-0.27$ \\
\hline $20.0-38.0$ & 砂質 & 410.0 & 2.0 & 249-294 & $0.16-0.20$ \\
\hline $38.0-46.0$ & 粘土 & 410.0 & 2.0 & $345-351$ & $0.09-0.10$ \\
\hline $46.0-52.0$ & 砂磔 & 410.0 & 2.0 & $221-228$ & $0.22-0.23$ \\
\hline $52.0-54.0$ & 砂磻 & 360.0 & 1.9 & 147 & 0.27 \\
\hline $54.0-65.0$ & 粘土 & 360.0 & 1.9 & $248-259$ & $0.16-0.17$ \\
\hline
\end{tabular}

\section{平面図を示す。}

兵庫県南部地震におけるこの建物の被害は、2 階から 5 階にかけて 南北方向の出入り口開口付き耐震壁がせん断破壊したほかは、耐震壁 等に幅 $1 \mathrm{~mm}$ 程度の亀裂が生じた程度の軽微なものであった。

この建物では、地下 3 階と 8 階で建設当初より地震観測が継続的に 行なわれてきており、兵庫県南部地震では、余震も含めて記録に成功 している。表 4 に観測された時刻歴加速度波形の最大值を示す。 地表面地動の逆算は、この記録の内最大値が大きい南北方向（建物 長辺方向、N309E) を対象として行なった。

弾塑性応答解析に用いた建物の質点系基礎固定モデルは、設計モデ ルを基に復元力特性の降伏耐力とひび割れ後剛性低下率を修正して作 成した。各層の履歴特性は武田モデルとした。復元力特性の修正に当 たっては、建物 8 階での絶対加速度ならびに建物地下 3 階と 8 階間の 相対変形とが観測結果とよく対応するように留意した。减衰は初期剛 性比例型の内部粘性減衰とし、减衰定数は 1 次モードに対して $3 \%$ と した。なお、ここで作成したモデルは、あくまで建物基礎におけるせ ん断力の時刻歴波形を求めることが目的であり、設計モデルを詳細に 再検討してその妥当性を検討するためのものではないことに留意され たい。

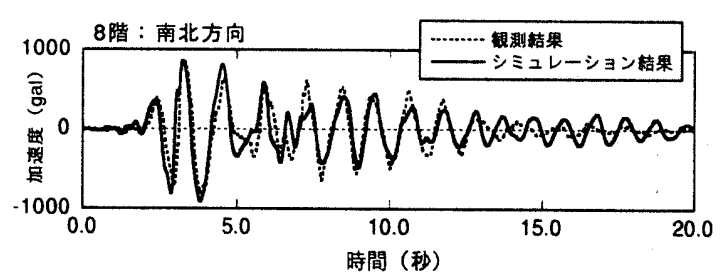

図 17 弾塑性応答解析結果と観測波形の比較

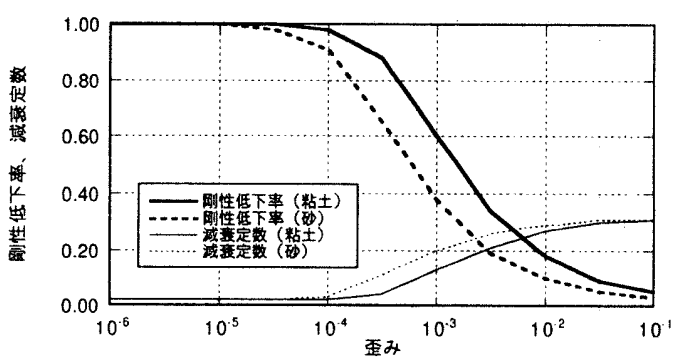

図 18 地盤の歪み依存特性

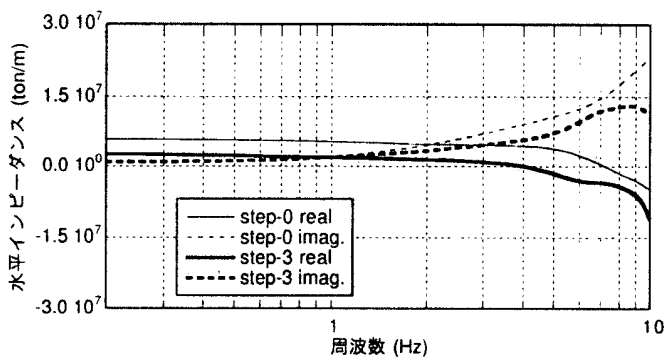

図 19 基礎のインピーダンス

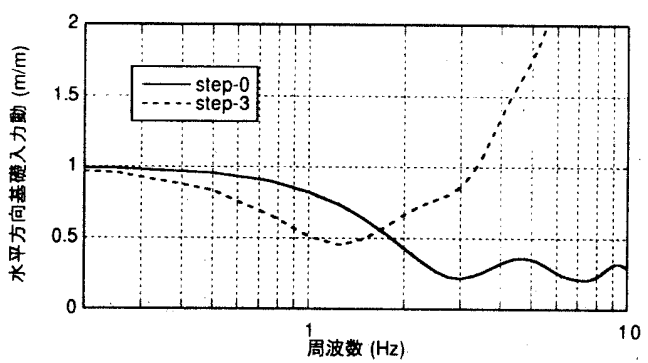

図 20 基磁入力動

このモデルの固有周期は 1 次モードで 0.75 秒であり、後述する地 盤ばねを考慮した場合の固有周期は 0.76 秒である。

この質点系モデルに地下 3 階観測波を入力し弹塑性応答解析を行な った。8階の応答加速度時刻歴波形を観測波と比較して図 17 に示す。 13 秒以降の後摇れを除けば解析結果は観測波とよく対応しているこ とがわかる。

地盤モデルは地震後に実施した PS 検層の結果に基づいてモデル化 した。表 5 に地盤モデルの初期地盤物性值を示す。地盤物性值の歪み 依存特性（G- $\gamma 、 h^{-}-\gamma$ 曲線）については、歪み依存の修正 R-0 モデ ルを用いて評価した ${ }^{4)}$ 。図 18 に、ここで用いた地盤物性值の歪み依 存特性について示す。

このモデルを用いて、前述した手法で自由地表面地動を逆算推定し た。困 19 に基礎のインピーダンスを、図 20 に基礎入力動をそれぞれ 示す。図中には初期地盤に対応するもの $(S t e p-0)$ と収束時のもの 


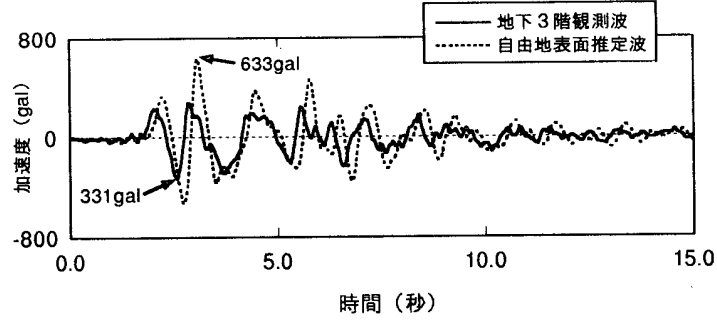

図 21 地表面推定波加速度波形

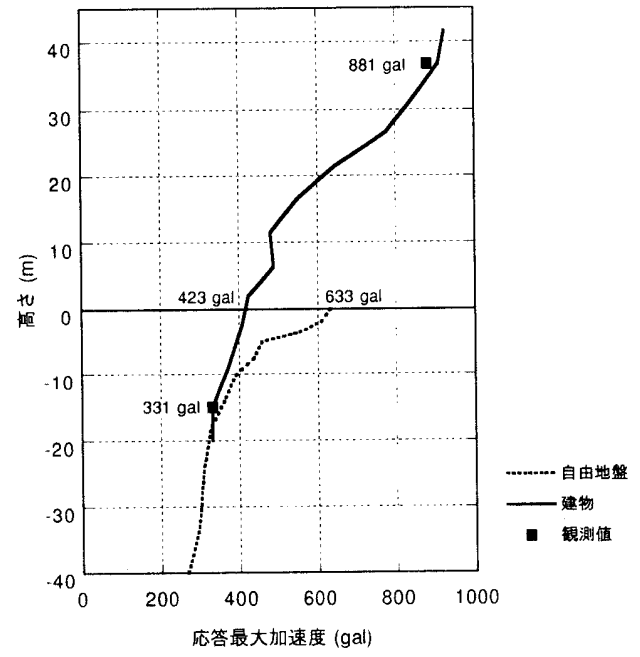

図 22 最大応答加速度分布図

(Step-3）とを示す。今回の解析では、収束にいたるまでに 3 回の綝 り返しを必要とした。表 5 には、収束時の地盤のせん断波速度 Vs'と 減衰定数 h’を示してある。なお、収束時の地盤の歪みレベルは、も つとも大きな層で $0.011(1.1 \%)$ 程度となっており、前節における新長 田駅前市街地住宅の場合の 6 倍程度の值を示している。

得られた自由地表面加速度波形を地下 3 階における観測波と比較し て図 21 に示す。最大值で見ると、観測波の $331 \mathrm{gal}$ に対し地表面推定 波では 633gal と約 90\%の增加（地表面に対し地下 3 階では約 $52 \%$ に 減少）になっていることがわかる。

図 21 の自由地表面加速度波形を、前節で得られた新長田駅前市街 地住宅での結果と比較すると、新長田の結果では建物内での観測波形 と自由地表面での推定波形が比較的似た形状をしているのに対して、

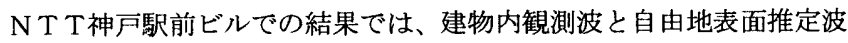
とがピークの大きさや波の位相等においてかなり差が見られる結果と なっている。これは、表 3 と表 5 の収束地盤定数に見られるごとく、 それぞれの検討における地盤の非線形化度合の差に起因する基礎入力 動（新長田については図 10 に、N T T 神戸駅前ビルについては図 20 に示されている）の違いによるものと思われる。すなわち、新長田に おける基礎入力動は $10 \mathrm{~Hz}$ 程度までの範囲において収束前後の差があ まり見られない、言い換えれば地盤があまり非線形化していないのに 対して、N T T の基礎入力動は地盤が強非線形領域に入ることにより $2 \mathrm{~Hz}$ 以上で大きな増幅を生じていることが影響しているのではないか と考えられる。

図 22 には建物と自由地表面の最大加速度分布を示す。図中には建 物における観測結果も併記して示す。図から、自由地盤では GL-5m よ

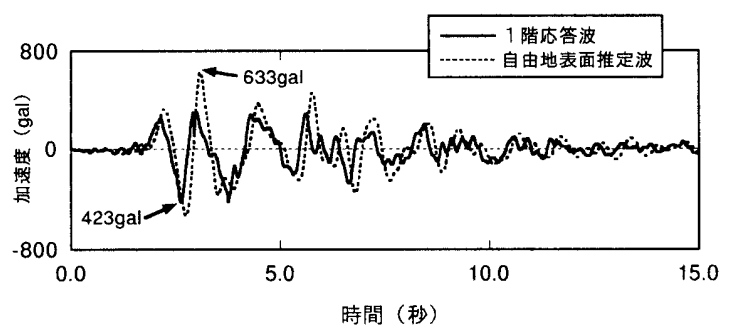

図 23 地表面推定波と 1 階忘答波の比較

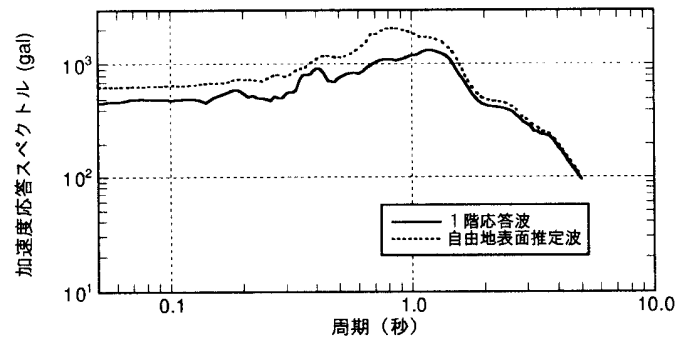

図 24 応答スペクトルの比較

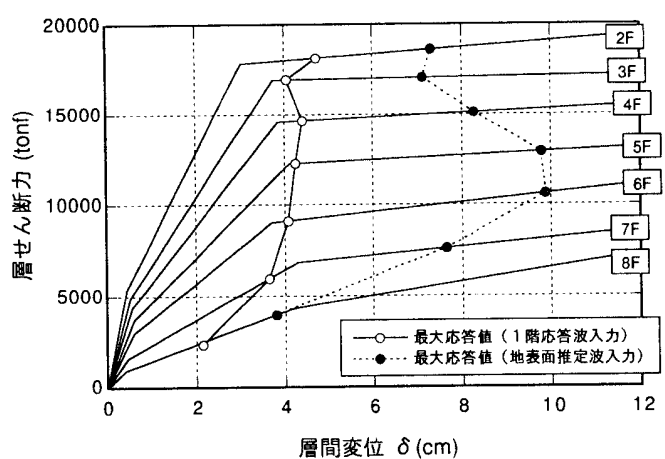

図 25 最大応答層せん断力

り上の表層で大きな増幅が見られることが分かる。また、建物地下階 の観測值は基礎底面位置の自由地盤と同程度の值を示すことがわかる 3), 5)。

次に、基礎有効入力動の低减効果について地表面高さで比較検討す るため、自由地表面波と、同じ高さでの建物応答すなわち地下 3 階固 定モデルに地下 3 階観測波を入力した際の 1 階応答波との比較を行な う。図 23 に、地表面推定波と 1 階店答波との波形の比較を示寸。最 大值で見ると、地表面推定波の 633gal に対し 1 階応答波では 423gal と約 $33 \%$ の減少になっていることがわかる。最大速度の比較では、 地表面推定波の 105kine に詨して 1 階忘答波では 101kine と、約 4\% の減少となっている。これらの值を建物基礎の観測值と比較して図 2、 3 に示寸 (OB)。図から、加速度については観測值と同様の傾向を 示すが、速度はやや小さ目の低減率を示すことが分かる。自由地表面 波と 1 階応答波とを加速度応答スペクトルで比較したものを図 24 に 示す。図から、1.5 秒程度より短周期では 1 階の応答と自由地表面と の差がみられることが分かる。新長田駅前住宅の場合と比較すると、 より長い周期から基礎有効入力動の差が現れていることが分かる。 次に、前述の質点系弾塑性モデルを 1 階固定としたものに地表面推 定波を入力して応答解析を行い、同じモデルに 1 階応答波を人力した 結果（地下 3 階固定モデルに地下 3 階観測波を入力したものと同じ結 
果となる）とどのような差が生じるかを比較した。応答解析結果を層 間最大応答で比較したものを図 25 に示す。図から、地表面推定波入 力の場合、8階を除くすべての階で最大応答値が大きく増加しており、 5 階から 6 階の中間階では特に大きく増加していることが分かる。こ れは、1 階応答波入力のレベルでほほ降伏点に達しているため、入力 の増加の割に大きな応答の増加をもたらしたためと考えられる。この 結果は 3.2 節の結果と同様に、建物への基礎有効入力動の評価が建物 被害をシミュレーションする上で重要であることを示唆している。

\section{4 まとめ}

本論文では兵庫県南部地震における強震観測記録に含まれている相 互作用の影響、相互作用による建物被害の低減効果等についての検討 結果を述べた。以下に得られた知見を列挙する。

（1）地表面と建物基礎とで同時観測された強震記録の最大加速度值 を比較したところ基礎は地表面に対して約 3 割の低減傾向があること が認められた。また、最大速度について同様な比較を行ったところ約 1 割の低減率を示し低減傾向は加速度に比べて小さいことがわかった。

(2) 激震地に建つ新長田駅前高層市街地住宅と神戸駅前中層事務所 ビルの二つの建物について建物基礎の記録から自由地表面の地震動を 逆算した。その結果、逆算による地表面の最大加速度と最大速度に対 する建物基礎の比は上記の同時観測記録と同様の低减傾向を示した。

（3）建物基礎の底面位置の最大加速度は、同じ媣さの自由地盤の最 大加速度にほぼ等しい值を示し、上記の低減効果の原因のひとつは基 礎底面位置以浅の表層地盤の増幅効果によるものであると推察された。

(4) 逆算地表面地震動とそれに対応する基礎有効入力動のスペクト ルの比較から、1 秒より短い周期において低減効果が認められた。

（5）逆算地表面地震動と基礎有効入力動を基礎固定の建物モデルに 入力してその応答值を比較した。前者による応答は後者によるものに 比べて大きくなることが示され、建物被害をシミュレーションする上 で基礎有効入力動の評価が重要であることが確認された。

\section{謝辞}

建物基䃈と自由地盤の同時観測記録に関するデータを借用するにあ たってお世話になった、関西電力（株）土木建築室、住宅都市整備公 団建築部、大阪府水道部、京都大学防災研究所および大阪工業大学建 築学科の各関係諸機関の方々に謝意を表します。

また、本研究成果は、兵庫県南部地震特別研究委員会・特定研究課 題 1 「強震動と設計用地震動との関係」のうち、SWG5-2（相互作用） の成果の一部をとりまとめたものである。委員各位には検討・とり纏 めの過程で貴重な意見を頂いた。記して謝意を表します。

[SWG5-2の委員構成］ ○主查、○幹事

赤木久真（NTTファシリティーズ）、飯場正紀（建設省建築研究所）、井 川望（鴻池組）、井口道雄（東京理科大学）、○犬飼伴幸（竹中工務 店）、井上貴仁（間組）、篠崎祐三（京都大学）、田守伸一郎（信州 大学）、二宮利文（NTT ファ测ティーズ）、長谷川正幸（清水建設）、林 康裕（清水建設）、福和伸夫（名古屋大学）、藤森健史（大林組）、 ○前田寿朗（大成建設）、三浦賢治（鹿島建設）、@安井譲（大林 組)、横山浩明（鴻池組）

なお、(株) 大林組技術研究所振動研究室の高野真一郎氏と同構造第 一研究室の高田香織氏には数值計算の一部を協力していただいた。こ こに記して謝意を表します。
参考文献

1）安井譲：相互作用の影響、日本建築学会兵軍県南部地震特別研究委員会第 1 回公開シンポジウム、特別研究 阪神・淡路大震災から一年 建築およひ都市 の防災向上に向けて pp. 19-22、1996.

2）建設省建築研究所：平成 7 年阪神淡路大震災建築震災調查委員会最終報告書 1996.

3）林康裕、宮腰淳一、田村和夫、川瀬博：1995 年兵庫県南部地震の低層建物被 害率に基つく最大地動速度の推定、日本建策学会構造系論文集、No. 494 、 pp. 59-66、1997.

4）二宮利文：NTT 神戸駅前ビルー地震観測記録と地震店答解析一、シンポジウ

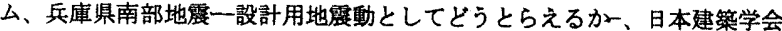
近畿支部耐震構造研究部会、 pp. 26-34、1996.

5）田村和夫、林康裕、護雅史、高橋郁夫：1995 年兵庫県南部地震における建物 被害と有効入力動の評価（その2）、日本建築学会大会学術講演梗概集 B-2、 pp. 515-516、1996.

6）栗本修：地船の材料非線形性を考慮した高層 RC 建物の地震応答解析、日本 建築学会大会学術講演梗概集 B-2、pp. 403-404、1996.

7）藤森健史、安井譲、若松邦夫、野畑有秀 : 高層 $\mathrm{RC}$ 構造物の強震時の基礎入 力動に関する研究、日本建築学会大会学術講演梗概集 B-2、pp. 397-398、 1995.

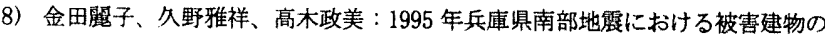
応答解析（その 1)、(その 2) 、日本建築学会大会学術講演梗概集 B-2、 pp. 517-520、1996.

9）半澤徹也、横田治彦：1995 年兵庫県南部地震の強震記録と建物の応答特性一 動的相互作用を考慮した検討一、日本建築学会大会学術請演梗概集 B-2、 pp. 511-512、1996

10）林康裕：值接基鿎構造物の基礎浮上りによる地震被害低減効果、日本建築学 会構造系論文集 第 485 号、pp. 53-62、1996.

11）林康裕、護雅史、渡辺宏一、田村和夫、金子美香、斉藤知生、横田治彦： 1995 年兵庫県南部地震における被災建物の動特性とシミュレーション解析、 清水建設研究報告、第 62 号、pp. 37-49、1995.

12）横山浩明：超高層 RC 建物の地震観測と挙動解析、シンポジウム、兵庫県南 部地震一設計用地震動としてどうとらえるが、日本建築学会近畿支部耐震 構造研究部会、pp. 1-17、1996.

13）古和田明、前田舁、森伸一郎、池田隆明、前川泰雄：超高 $\mathrm{RC}$ 煙突の兵庫県 南部地震に対する設計モデルの検証（その1）、日本建築学会大会学術講演 梗概集 B-2、pp. 357-358、1997.

14）宮本裕司、酒向裕司、古山田耕司、三浦賢治：1995 年兵庫県南部地震におり る地盤条件を考慮した構造物の地震応答解析（その 3）、日本建筑学会関東 支部研究報告集、pp. 73-76、1995.

15）土井敏治、古和田明、松村孝夫、木田隆、前田昇：地震観䫀記録による火 力発電所大規模構造物の振動性状に関する研究、その 1.タービン建家の振娌 性状について、日本建築学会大会学術講演梗概集 B、構造 I pp. 1155-1156、 1994.

16）大場新太郎、三村浩平：地震動強さが建物の固有周期に及ほす影揰、日本建 築学会近畿支部研究報告集、pp. 205-208、1995

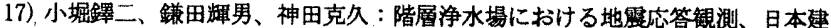
築学会近幾支部研究報告集、pp. 77-80、1981.

18）安井蚊、高野真一郎、中村充、高田香織：新長田駅前市街地住宅における兵 庫県南部地震観測波の検討、シンボジウム、兵庫県南部地䈨一設計用地震動 としてどうとらえるかー、日本建策学会近幾支部耐震構造研究部会、pp. 3544、 1996.

19) H. Tajimi : Predicted and Measured Vibrational Characteristics of a Large-Scale Shaking Table Foundation, Eighth World Conference on Earthquake Engineering, Vol III, pp. 873-880, 1984.

20）高野真一郎、前野仁、安井譲 : サブストラクチャー法を用いた群杭基磷の三 次元地震応答解析 その 6、日本建築学会大会学術講演梗概像 B、pp. 595596、 1992.

21）沢井布兆、江戸宏彰、津田和明、高田香織：SRC 造 25 階建て集合住宅の被害 と解析、コンクリート工学、Vol. 34、No. 11、1996 年 11 月号、pp. 37-41.

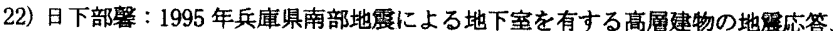

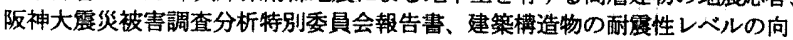
上に向けて、日本建築学会近畿支部阪神大霞災被害調查分析特別委員会、 pp. 179-192、1997 年 10 月.

23）土岐憲三：新体系土木工学 11 「棈造物の耐震解析」、技報堂出版、pp. 73-74、 1982

24）石原研而：土質動力学の基碦、鹿岛出版会、 pp. 199-201、1976. 